\title{
Komposisi hasil tangkapan jaring insang dasar di perairan pantai Sario, Teluk Manado
}

\author{
Catch composition of bottom gill nets in the coastal waters of Sario, Manado Bay
}

\author{
Markus Morin ${ }^{*}$, JohnNy Budiman, AgliUs T.R. TElleng dan Meta S. SOMPIE
}

Program Studi Pemanfaatan Sumberdaya Perikanan, Fakultas Perikanan dan Ilmu Kelautan, Universitas Sam Ratulangi, Manado 95115

\begin{abstract}
ABSTRACK
This research was conducted in coastal waters of Sario, Manado Bay using three units of bottom gill nets with the size of mesh 3, 4, and 5.5 inches to examine the composition of demersal fish catches using a descriptive method which based on a case study. This study took place from May 2013 to August 2013. The catches of gill net 3 inches based on total catch were dominated by long-finned bigeye, smudgespot spine foot, blue-striped seaperch, and bartailed goat fish, and based on the catch weight the dominant species were cobia, rays, hussar and ornate emperor, four inches gill net were dominated by ryas, dogtooth tuna, crab, and malabar trevally, and based on the weight of the catch the dominant species were dogtooth tuna, sharks, malabar trevally, and rays; mesh size 5.5 inches were dominated by dogtooth tuna, rays, sharks, and malaba trevally, and based on the weight of the catch, the catch were dominated by dogtooth tuna, and shark. Correlation between the mesh size of gill nets and the average weight of catches was very high with the value of $\mathrm{R}^{2}=0.99$.
\end{abstract}

Keywords: bottom gill nets, mesh size, catch weights, Manado Bay

\begin{abstract}
ABSTRAK
Penelitian ini dilakukan di perairan pantai Sario, Teluk Manado menggunakan alat tangkap jaring insang dasar tetap sebanyak 3 unit dengan ukuran besar mata jaring 3, 4, dan 5,5 inci untuk melihat komposisi hasil tangkapan ikan demersal dengan menggunakan metode deskriptif yang didasarkan pada studi kasus. Penelitian berlangsung sejak Mei 2013 sampai dengan Agustus 2013. Hasil tangkapan jaring insang dengan ukuran mata jaring 3 inci berdasarkan jumlah tangkapan didominasi ikan swangi, beronang, ikan merah dan biji nangka, dan berdasarkan bobot tangkapan didominasi oleh gabus laut, pari, bambangan dan lencam; ukuran mata 4 inci didominasi pari, tuna gigi anjing, kuwe dan rajungan, dan bobot tangkapan didominasi oleh ikan tuna gigi anjing, hiu, pari dan kuwe; ukuran mata 5.5 inci didominasi oleh jenis ikan tuna gigi anjing, pari, hiu dan kuwe, dan bobot tangkapan didominasi oleh tuna gigi anjing dan hiu. Korelasi antara ukuran mata jaring dengan rata-rata bobot tangkapan jaring insang dasar sangat erat dengan nilai $\mathrm{R}^{2}=0.99$.
\end{abstract}

Kata-kata kunci: jaring insang dasar, besar mata jaring, bobot tangkapan, Teluk Manado

\section{PENDAHULUAN}

Sebagai negara kepulauan, prospek pembangunan perikanan Indonesia menjadi salah satu kegiatan ekonomi yang sangat strategis dinilai sangat cerah. Potensi sumberdaya perikanan di perairan Indonesia diperkirakan sebesar 6,6 juta ton/tahun meliputi sumberdaya perikanan pelagis 3,5 juta ton/tahun, dan demersal 3,1 juta ton/tahun (Nontji, 2005).

\footnotetext{
* Penulis untuk penyuratan: email: markusmorin19@gmail.com
}

Salah satu sumberdaya perikanan yang potensial dan masih belum dimanfaatkan secara maksimum adalah sumber daya ikan demersal. Ikan demersal adalah ikan yang umumnya hidup di daerah dekat dasar perairan. Sumberdaya ikan demersal terbagi dua berdasarkan ukuran yaitu ikan demersal besar seperti kelompok kerapu (grouper) dan kakap (snapper). Ikan demersal ekonomis penting yang paling umum antara lain adalah kakap merah, bawal putih, manyung, kuniran, gulamah, layur dan peperek (Junaidi, 